Article

\title{
Evolution of Sedimentary Basins as Recorded in Silica Concretions: An Example from the Ionian Zone, Western Greece
}

 \\ 1 Department of Geology, Saint Mary's University, Halifax, NS B3H 3C3, Canada \\ 2 Natural Resources Canada, Geological Survey of Canada (Atlantic), Bedford Institute of Oceanography, \\ P.O. Box 1006, Dartmouth, NS B2Y 4A2, Canada; david.piper@canada.ca \\ 3 Laboratory of Sedimentology, Department of Geology, University of Patras, 26504 Patras, Greece; \\ geo09093@upnet.gr (N.B.); a.zelilidis@upatras.gr (A.Z.) \\ * Correspondence: gpiper@smu.ca
}

Citation: Pe-Piper, G.; Piper, D.J.W.; Bourli, N.; Zelilidis, A. Evolution of Sedimentary Basins as Recorded in Silica Concretions: An Example from the Ionian Zone, Western Greece. Minerals 2021, 11, 763. https:// doi.org/10.3390/min11070763

Academic Editor: Ricardo Ferreira Louro Silva

Received: 20 June 2021

Accepted: 9 July 2021

Published: 15 July 2021

Publisher's Note: MDPI stays neutral with regard to jurisdictional claims in published maps and institutional affiliations.

Copyright: (c) 2021 by the authors. Licensee MDPI, Basel, Switzerland. This article is an open access article distributed under the terms and conditions of the Creative Commons Attribution (CC BY) license (https:// creativecommons.org/licenses/by/ $4.0 /)$.

\begin{abstract}
Chert concretions in thick limestone successions preserve a more complete paragenetic sequence of diagenetic minerals than their host limestone and interbedded shale. The goal of this study was to test the possible presence of a high-temperature mineralising system in the Ionian basin of western Greece. Upper Cretaceous chert nodules were sampled at Araxos, where rocks are highly faulted and uplifted by salt diapirism, and on Kastos Island, on the flanks of a regional anticline. Chert concretions have microporosity produced by recrystallisation of opal to quartz and fractures produced in the brittle chert during basin inversion. Diagenetic mineral textures were interpreted from backscattered electron images, and minerals were identified from their chemistry. Diagenetic minerals in pores and veins include sedimentary apatite (francolite), dolomite, Fe-chlorite, Fe oxidehydroxide mixtures, sphalerite, barite and calcite. Sphalerite is restricted to Araxos, suggesting that inferred basinal fluids were hotter and more saline than at Kastos. At Araxos, the Fe oxide-hydroxide also includes minor $\mathrm{Cu}, \mathrm{Zn}$, and $\mathrm{Ni}$. Whether the transported metals were derived from sub-salt clastic rocks and basement, or from enriched Mesozoic black shales, is unclear. The effectiveness of this novel approach to understanding fluid flow history in thick limestone successions is validated.
\end{abstract}

Keywords: chert; veins; pores; sphalerite; francolite; barite; basinal fluids; salt tectonics

\section{Introduction}

Siliceous (chert) concretions in limestones provide an important record of diagenetic, tectonic, and fluid-flow events in limestone-dominated sedimentary basins. In these limestones, opal precursors of many chert concretions and beds form early in the diagenetic paragenesis at redox controlled boundaries [1], but recrystallisation of opaline silica to quartz is unusual in rocks younger than Miocene in the modern ocean [2] and takes place at elevated temperatures following burial [3]. This replacement of opal by quartz creates pervasive microporosity in many cherts [4-6]. In some cases, chert precipitation may occur quite late in the diagenetic paragenesis without an opal precursor $[7,8]$. During tectonic deformation of limestone successions, fracturing and faulting are concentrated in a distinctive manner in and around chert concretions [9]. Mineral phases precipitated in veins and in the microporosity of chert concretions have the potential to preserve a record of basinal fluid flow first during burial and later during tectonic inversion.

In this study, we have investigated the record of fluid flow in Cretaceous deep-water limestones from the Ionian zone of western Greece using the record preserved in chert concretions. The Ionian zone (Figure 1) forms part of the eastern continental margin of the Adria microcontinent [10]. The Hercynian igneous and metamorphic basement of Adria is overlain by terrestrial clastic rocks of Permo-Triassic age, referred to as the Verrucano facies in Italy [11] and homologous successions east of the Ionian zone in the Peloponnese are known as the Phyllite-Quartzite series [12]. The Verrucano facies is followed by thick 
Triassic evaporites in Italy and in the Ionian zone. These comprise halite with minor nodular anhydrite in the Ionian zone [13], but anhydrite is dominant nearer the basin margin in northern Italy [14]. Active rifting and subsidence of the Ionian zone is referred to as syn-rift from early Jurassic to early Eocene $[15,16]$, when mostly limestones accumulated. The Jurassic limestones are principally pelagic, but calciturbidites are common in the Upper Cretaceous. Important Jurassic deep-water phosphorite deposits occur in the northern Ionian zone $[17,18]$. The compressive phase of the Ionian basin (early Eocene-middle Miocene) led to the formation of a fold-and-thrust belt with detachment along the Triassic evaporites and the development of salt-cored anticlines and diapirs in places $[15,19,20]$.

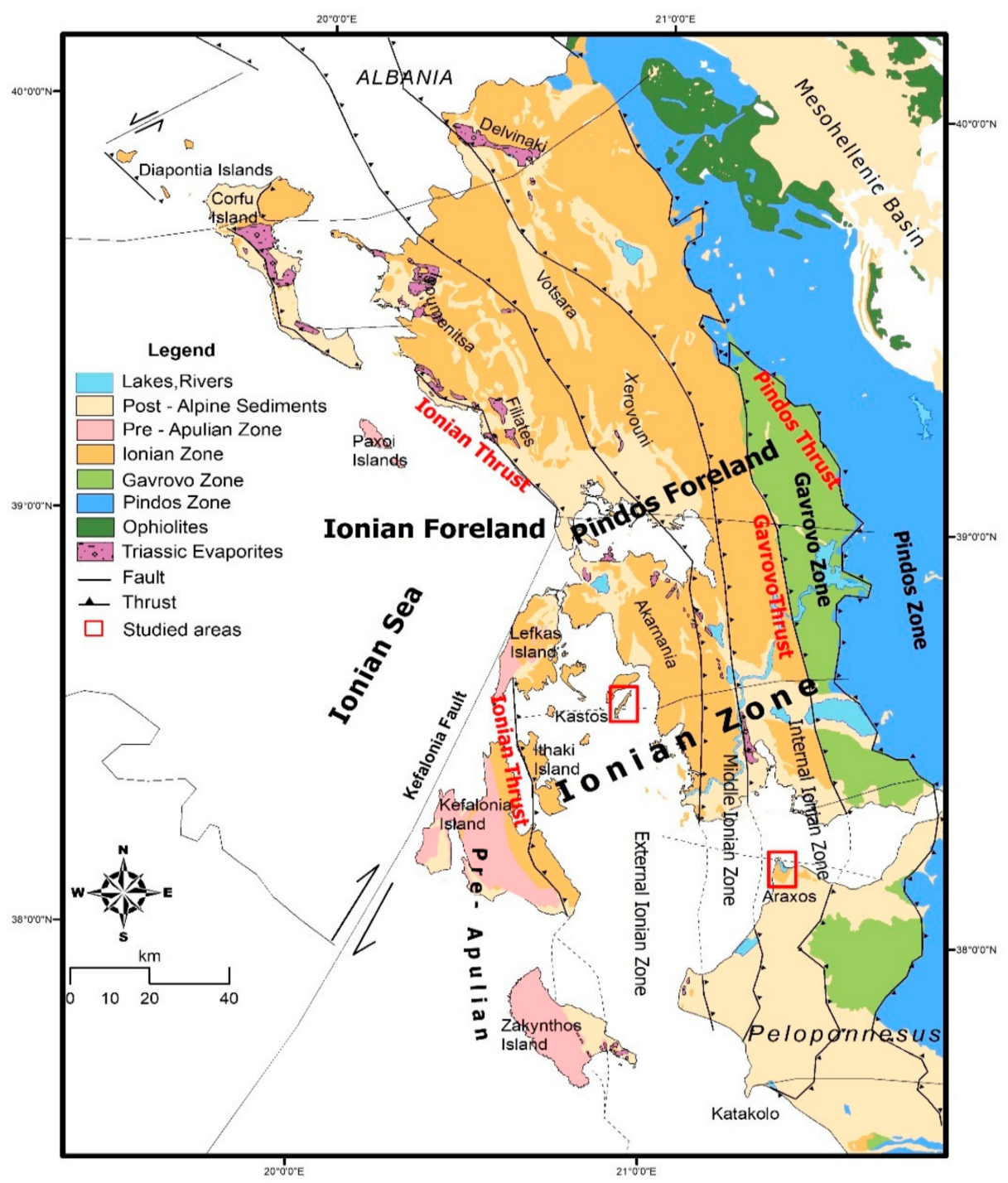

Figure 1. Regional map of the Ionian zone of Greece, showing the location of the study areas (red boxes). Map modified from [20].

This study investigates large, siliceous concretions from Upper Cretaceous 'Senonian' limestones. Concretions from two localities are compared: the highly deformed outcrops at Araxos in the NW Peloponnese and the less deformed outcrops at Kastos Island (Figure 2). The overall mineralogy of the siliceous concretions in limestone from these localities has been recently reported [20]. That study showed that quartz is the dominant mineral with rare to common residual calcite. The presence of moganite and opal-A suggests that quartz recrystallised from original amorphous silica. That amorphous silica in places experienced synsedimentary deformation. 


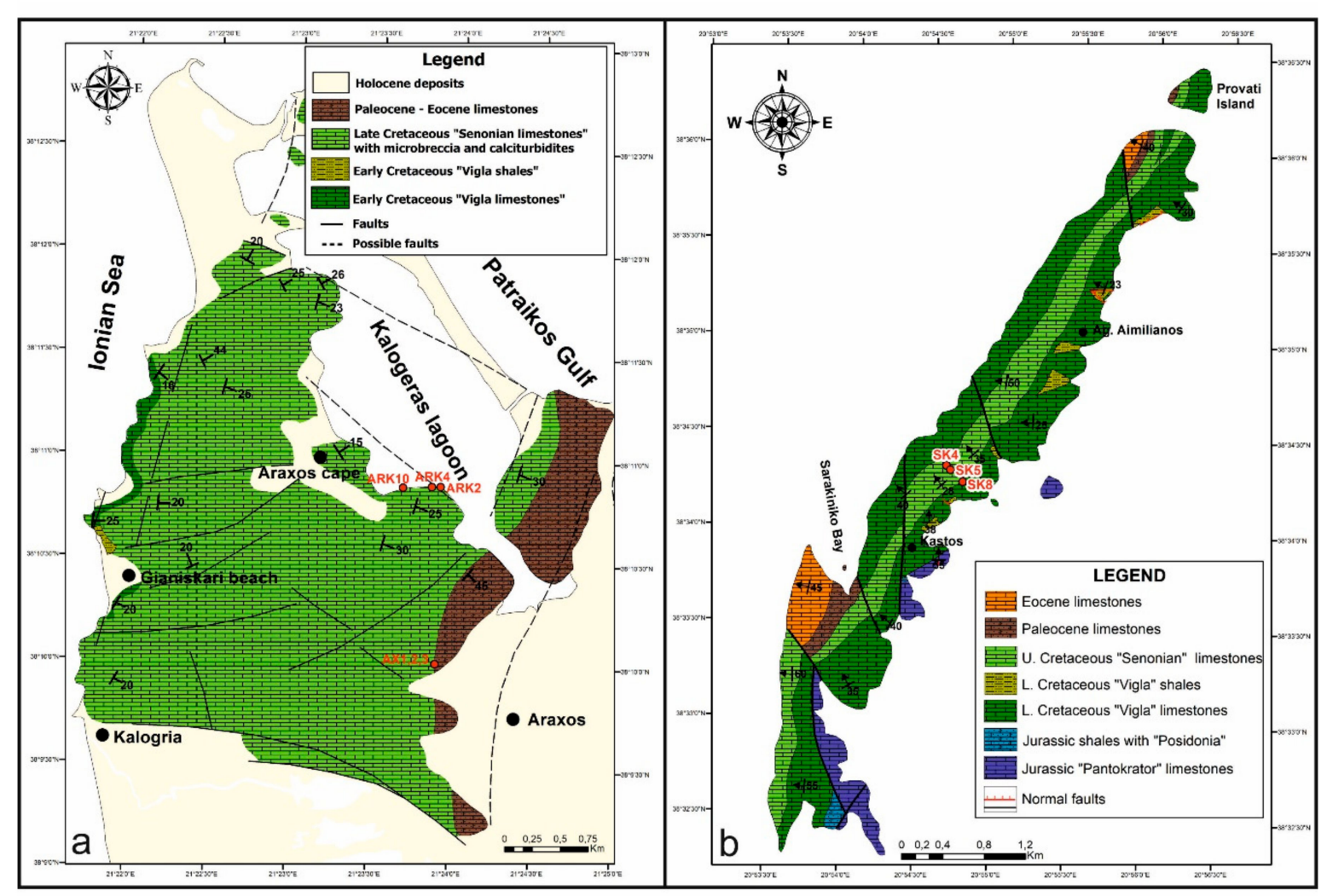

Figure 2. Location maps for (a) Araxos and (b) Kastos samples. Map modified from [20].

The present paper studies the chemistry of minerals and their textural relationships within these siliceous concretions and uses such observations to determine their late diagenesis. First, we establish the diagenetic paragenesis of the chert concretions. Then, we use the mineralogical data to explore the effects of authigenesis, diagenesis, and flow of basinal fluids on the mineralogy of the concretions. Finally, we relate geographic variation in mineralogy to the structural setting of the two studied outcrops and the role of salt tectonics. The overall goal was to test the possible presence of a high-temperature mineralising system in the Ionian zone, suggested by our studies of river sands in northwestern Greece.

\section{Materials and Methods}

Nine hand specimens of chert nodules and bedded chert were studied from the socalled Senonian Limestones at two localities-six from Araxos (Figure 2a) (samples AX1, 2, 3 and ARK2, 4C, 10) and three from Kastos (Figure 2b) (SK4, SK5, SK9). Polished thin sections were made from all samples; multiple sections are indicated as A, B, C, etc. All polished thin sections were studied by optical microscope and eight (AX1A, AX1B, AX1C, AX2, AX3, ARK2, SK4a, and SK5) were selected for detailed study. Carbon-coated polished thin sections were analysed using a Leo 1450 VP scanning electron microscope (SEM) (Zeiss, Jena, Germany) that has a maximum resolution of up to $3.5 \mathrm{~nm}$ at $30 \mathrm{kV}$. This SEM is also equipped with an INCA X-max $80 \mathrm{~mm}^{2}$ silicon-drift detector energy dispersive spectroscopy (EDS) system (Oxford Instruments, High Wycombe, UK), with a detection limit $>0.1 \%$. The EDS system uses a single cobalt standard, and precision is better than $1 \%$ for elements above $\mathrm{Ne}$ in the periodic table that are present at levels above $2 \%$. Backscattered electron (BSE) images were acquired to show mineral textures and EDS analyses were used to identify minerals. The details of methods for the analytical data in this paper are as in [21]. Mineral abbreviations are from Whitney and Evans [22].

The samples are fine-grained, and the diameter of the beam used for the EDS analyses was 10 microns, resulting in many analyses that contain more than one mineral component, especially for later minerals that appear to fill micropores and/or hairline veinlets in the 
host rock. Such mineral contaminants are mostly silica (microcrystalline quartz) and, to a lesser extent, calcite. Pure mineral analyses generally can be readily distinguished from mineral mixtures (Supplementary Materials S1-S9 and S11-S13).

\section{Results}

\subsection{Hand Specimen Observations}

The cherts studied from Araxos consist either of discrete concretions with an ellipsoidal shape parallel to bedding (Figure 3A) or form bedding-parallel more or less continuous beds of chert (Figure 3B). Ellipsoidal concretions commonly have a black core of quartz and a lighter coloured rim with dispersed residual calcite (Figure 3C). Some lighter patches of mainly calcite appear to represent bioturbation in the original limestone (Figure 3C,E). The bedded cherts also include lenticular patches of black quartz and bedded lighter coloured layers with more calcite (Figure 3B,D). All cherts are cut by joints and veinlets (Figure 3C-E), mostly perpendicular to bedding, with filled veins typically $10-30 \mu \mathrm{m}$ wide (Figure 4). Some veinlets and chert adjacent to them have an ochreous colour suggestive of iron (hydr-) oxide (Figure 3D). Joints and veins are more abundant in pure quartz concretions than in lighter coloured chert with residual calcite (Figure 3C,D).

The cherts from Kastos are also either nodular or bedded (Figure 9 of [20]). The samples chosen for analysis had more complex internal zoning from limestone to chert than is seen at Araxos, with irregular patches of residual limestone (Figure 3E,F). They also show irregular patches of ochreous material (Figure 3G). In some concretions, the final replacement of quartz-calcite mixtures by pure quartz takes place in mm-scale darkcoloured spherules (Figure 3F,G).

\subsection{Petrography and Paragenetic Sequence}

In the four samples from Araxos (AX1, 2, 3, and ARK 2), the dominant mineral is microcrystalline quartz, making up $>99 \%$ of the 'quartz zone', but in many places with variable amounts of calcite relics ('mixed zone'), where the calcite patches are up to tens of microns in size, but the quartz in many cases is 1-10 $\mu \mathrm{m}$ in size (Figure 4F). Their EDS analyses (Supplementary Materials S1-S9) show that in addition to quartz and calcite, there is Fe oxide/hydroxide (FeOhy), barite (brt), sphalerite (sp), pyrite (py), sedimentary apatite (ap), chlorite (chl), and rare grains of zincite that mostly fill fractures as veinlets (Figure 4) and micropores (Figure 5). Their mode of occurrence suggests that they are late in the sequence of events that have affected the studied rocks, after the conversion of opal to quartz.

In sample SK5 from Kastos (Figure 4F,G), in addition to quartz and calcite relics, other minerals identified include common FeOhy, rare sedimentary apatite, and very rare pyrite, monazite, a titania mineral, and zircon. In sample SK4a (Figure 5H) from the same locality, minor minerals identified include common barite and FeOhy, and very rare monazite and ilmenite (Supplementary Material S13). The principal difference in the Kastos samples from Araxos is the absence of sphalerite. 


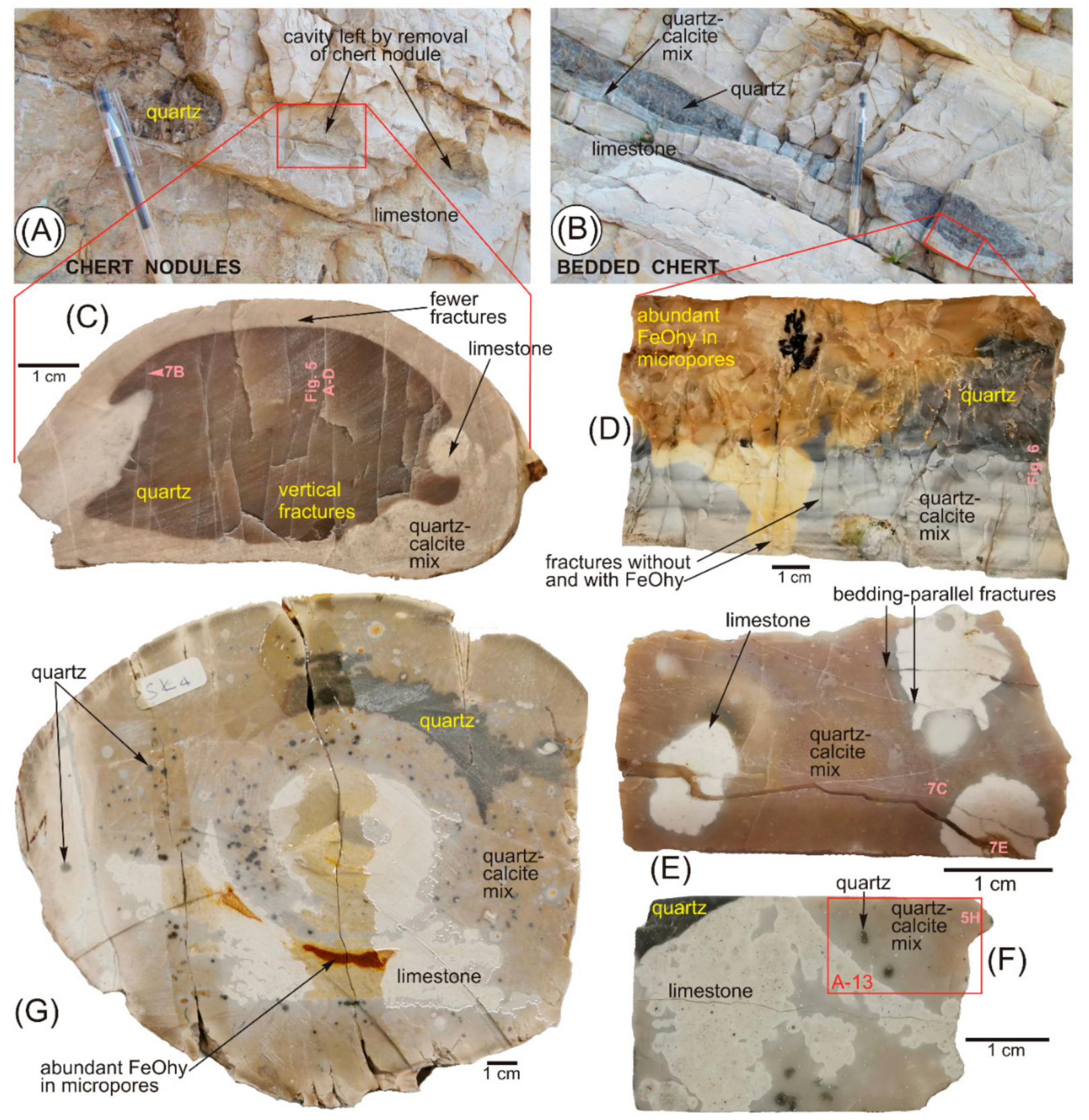

Figure 3. Field and hand specimen photographs of chert concretions (bedding plane horizontal for hand specimens): (A) field setting of sample AX1; (B) field setting of sample AX2; (C) highly fractured nodular chert concretion (sample AX1); (D) highly fractured bedded chert concretion (sample AX2); (E) nodular chert concretion (sample SK5); (F) part of nodular chert concretion (sample SK4a), showing the location of thin section in Supplementary Material S13. (G) Complex nodular chert concretion (sample SK4). 

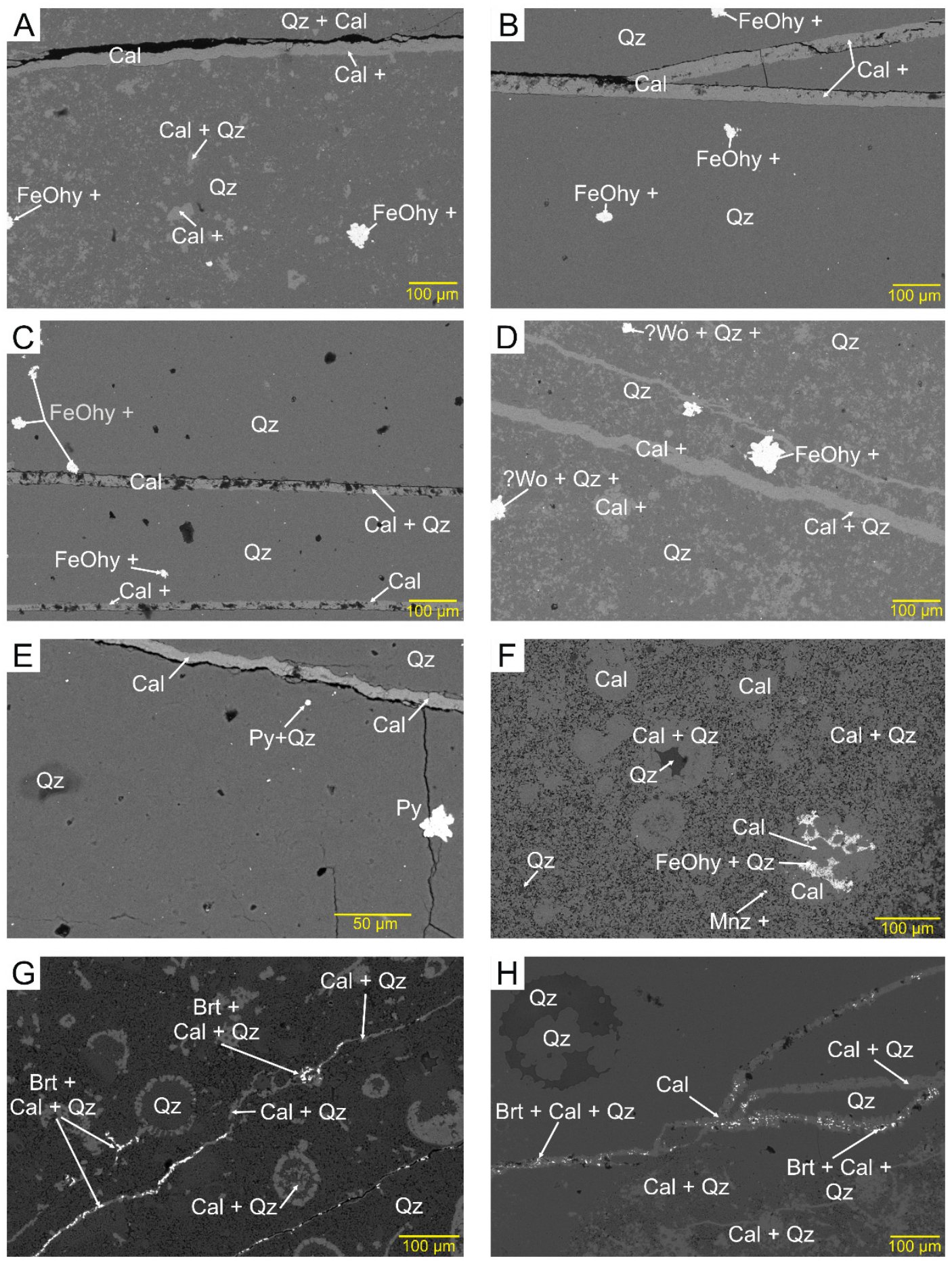

Figure 4. Backscattered electron images showing veinlets in chert. Mineral abbreviations throughout from Whitney and Evans (2010) [22] based on EDS chemical analyses, two or more minerals indicate a mixture of minerals in the $10 \mu \mathrm{m}$ analytical spot, + indicates additional elements not accounted for in the identified minerals. FeOhy $=$ unidentified Fe oxide and hydroxide minerals: (A) calcite veinlet in a mixed quartz-calcite zone (AX1B); (B) horizontal and oblique calcite veinlets in a quartz zone (AX1B); (C) Two horizontal calcite veinlets in quartz (AX1A); (D) two oblique calcite veinlets (AX1C); (E) quartz cut by calcite veinlet, with pyrite as specks and as an aggregate that cuts a hairline fracture (AX3); (F) cluster of hairline veinlets and irregular porous patches of FeOhy in a mixed quartz-calcite zone that also contains fossil relics made of calcite (SK5); (G) mixed quartz-calcite, rich in relics of fossils, cut by hairline veinlets of barite and calcite (SK5); (H) mixed quartz-calcite with a complex system of veinlets made up of calcite and barite specks (SK4a). 

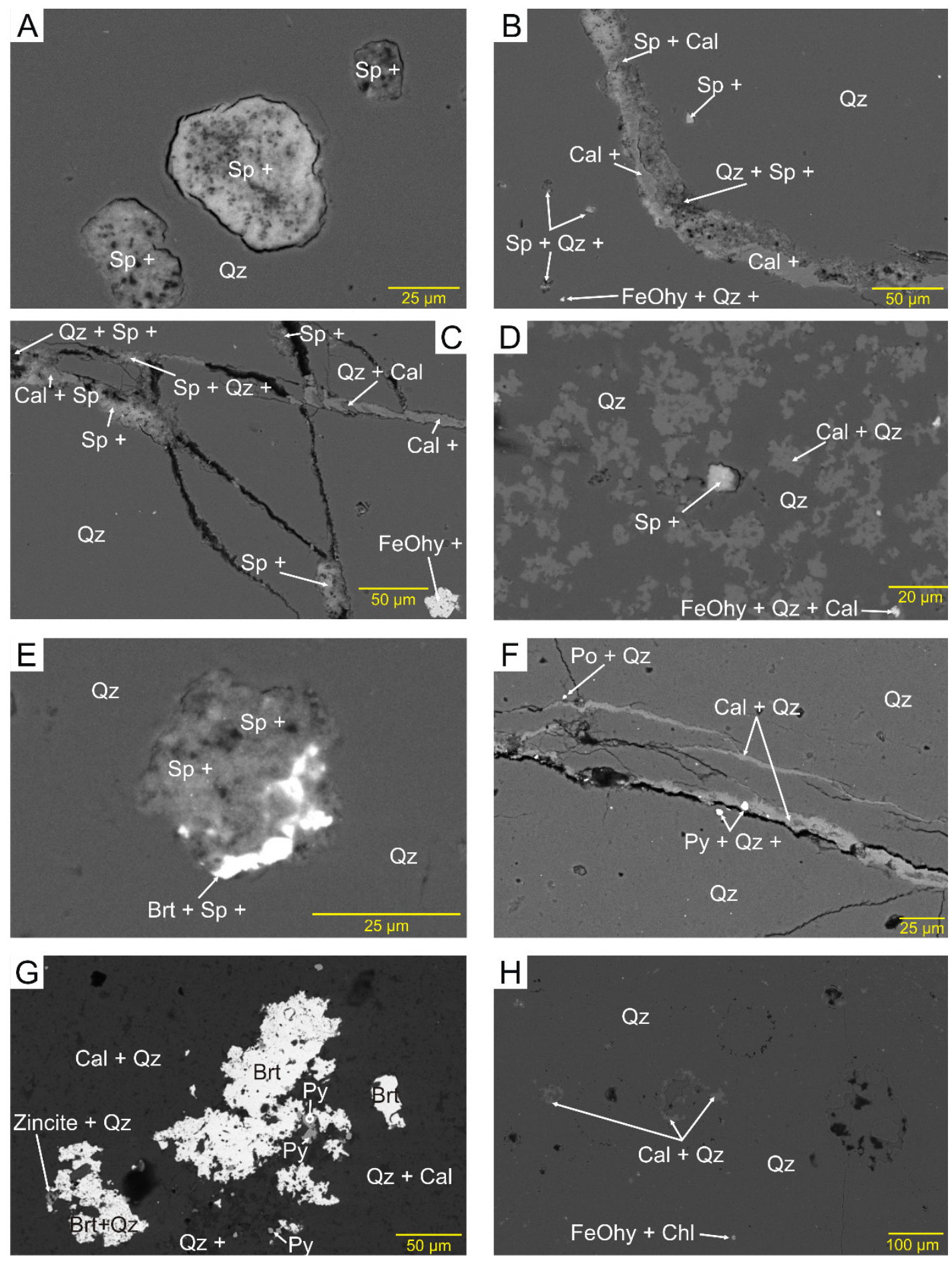

Figure 5. Backscattered electron images showing minerals in pores: (A) voids in quartz filled with sphalerite, clay, and probably calcite (AX1B); (B) quartz with scattered specks of sphalerite and a vein filled with calcite, sphalerite, and clay (AX1B); (C) rare FeOhy grains probably filling voids and a network of veinlets partly filled with sphalerite, calcite, and traces of clay (A1XB); (D) mixed quartz and calcite zone with scattered patches of calcite and FeOhy and a void partly filled with sphalerite, clay and probably calcite (AX1B); (E) sphalerite filling void with barite at the rim (AX3); (F) complex system of veinlets partly filled with calcite, and specks of pyrite and probably pyrrhotite (AX3); (G) large patches of barite, pyrite, and zincite partly filling voids (AX3); (H) quartz with microporosity and rare-scattered specks of probable chlorite (SK4a). 
Microporosity is common in both the Araxos and Kastos samples, some in the form of polygonal pores with straight outlines, and is better expressed in the quartz zones than in the mixed zones (e.g., Figures $4 \mathrm{C}$ and $5 \mathrm{~A}, \mathrm{E}, \mathrm{H}$ ). In Figure 6, as the proportion of calcite decreases, the microporosity in quartz appears to increase. Not all microporosity is polygonal and equant; some are smoothly round (Figure 5A), some are elongated along the bedding plane (e.g., Figure 7A) and calcite veinlets cut preexisting voids (Figure 7B). Parts of the Kastos concretions have microfossils not replaced by quartz. These areas also have less microporosity than typical Araxos samples (Figure 4G).
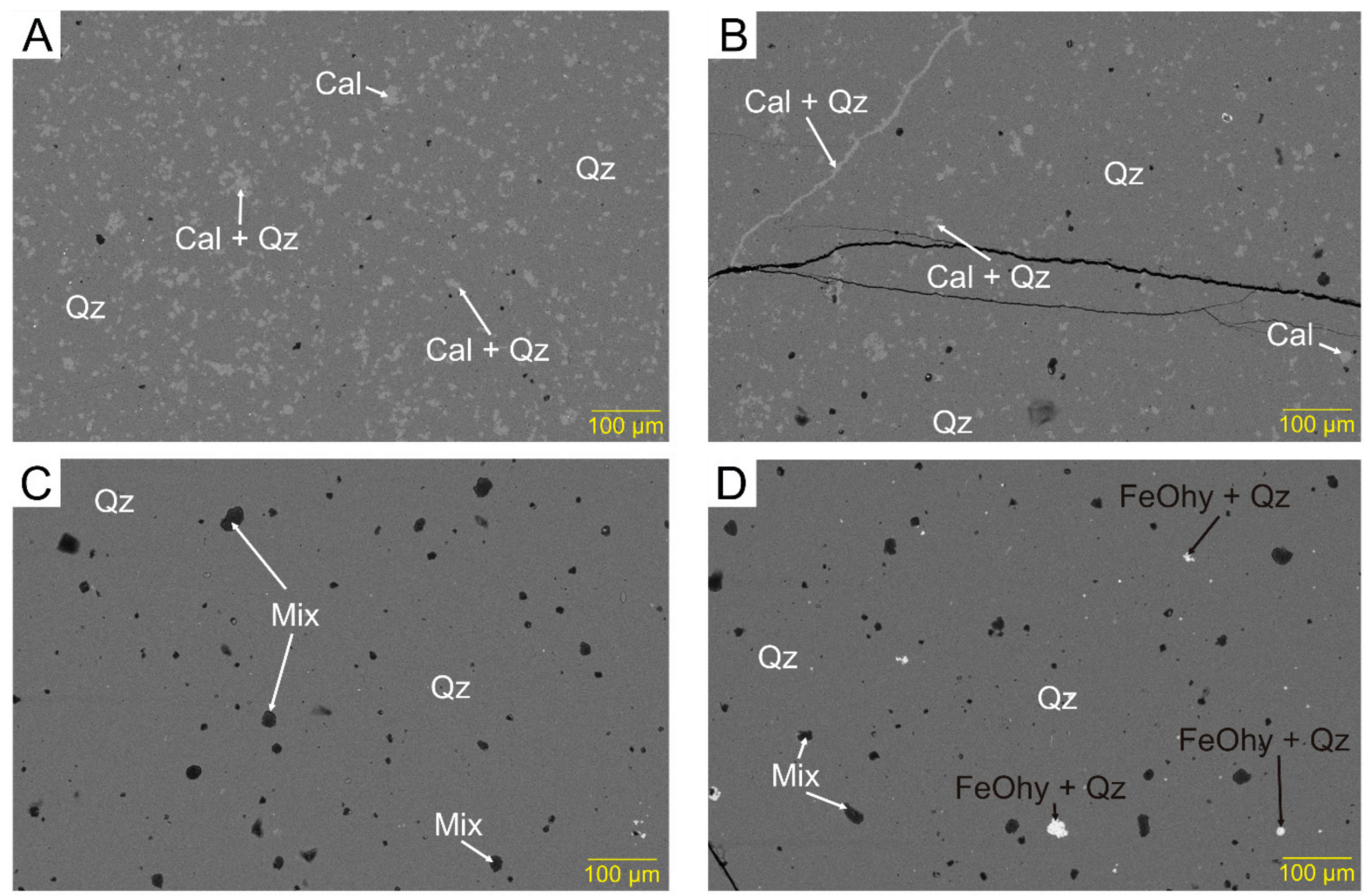

Figure 6. Backscattered electron images showing a gradual increase in microporosity as the proportion of quartz increases at the expense of calcite, from (A-D). In (D), common FeOhy in pores. (AX2).

Calcite veinlets, single or in a system of veinlets, occur perpendicular, oblique, or parallel to bedding (Figures $4 \mathrm{C}-\mathrm{E}$ and $5 \mathrm{~B}, \mathrm{C}$ ) in both quartz and mixed zones. Calcite also fills irregular fractures (Figure 5F). Some calcite veinlets incompletely fill the fractures (Figure 5C,F). The same veinlets may host a number of other late minerals.

\subsection{Mineral Chemistry \\ 3.3.1. Sphalerite}

Small late minerals $<10 \mu \mathrm{m}$ in size, such as sphalerite, are best identified from their chemistry, even when the analysis has been diluted by host quartz or calcite. Sphalerite occupies micropores with polygonal straight outlines (Figure 5A-D) in both quartz and mixed zones at Araxos. It also occurs in single or systems of veins together with calcite (Figure 5B,C). Sphalerite analyses show a strong positive correlation between $\mathrm{S}$ and $\mathrm{Zn}$ (Figure 8A), despite variable dilution by quartz and/or calcite. A few grains of zincite are present in sample AX3 (Figure 5G).

\subsubsection{Barite}

Barite, although present at both Araxos and Kastos, varies among samples in abundance and mode of occurrence. In the Araxos samples, AX1 and AX3 barite occur filling 
voids (Figure 5E), in large aggregates of crystals that appear to have replaced calcite (Figure 5G and Supplementary Materials Figure S5.16), and in hairline fractures, either alone or as bright spots on calcite (Figure 7F). In both samples AX1 and AX3, in a few voids partly filled by barite, sphalerite is also present (Figure 5E), suggesting that the two minerals are probably contemporaneous. In the Kastos samples, barite is rarer, occurring only in mixed zones in samples SK5 and SK4a. The barite occurs either as bright spots filling voids or as bright spots, with or without calcite, along hairline fractures (Figure $4 \mathrm{G}, \mathrm{H}$ ). No large aggregates of barite crystals have been seen in the Kastos samples.
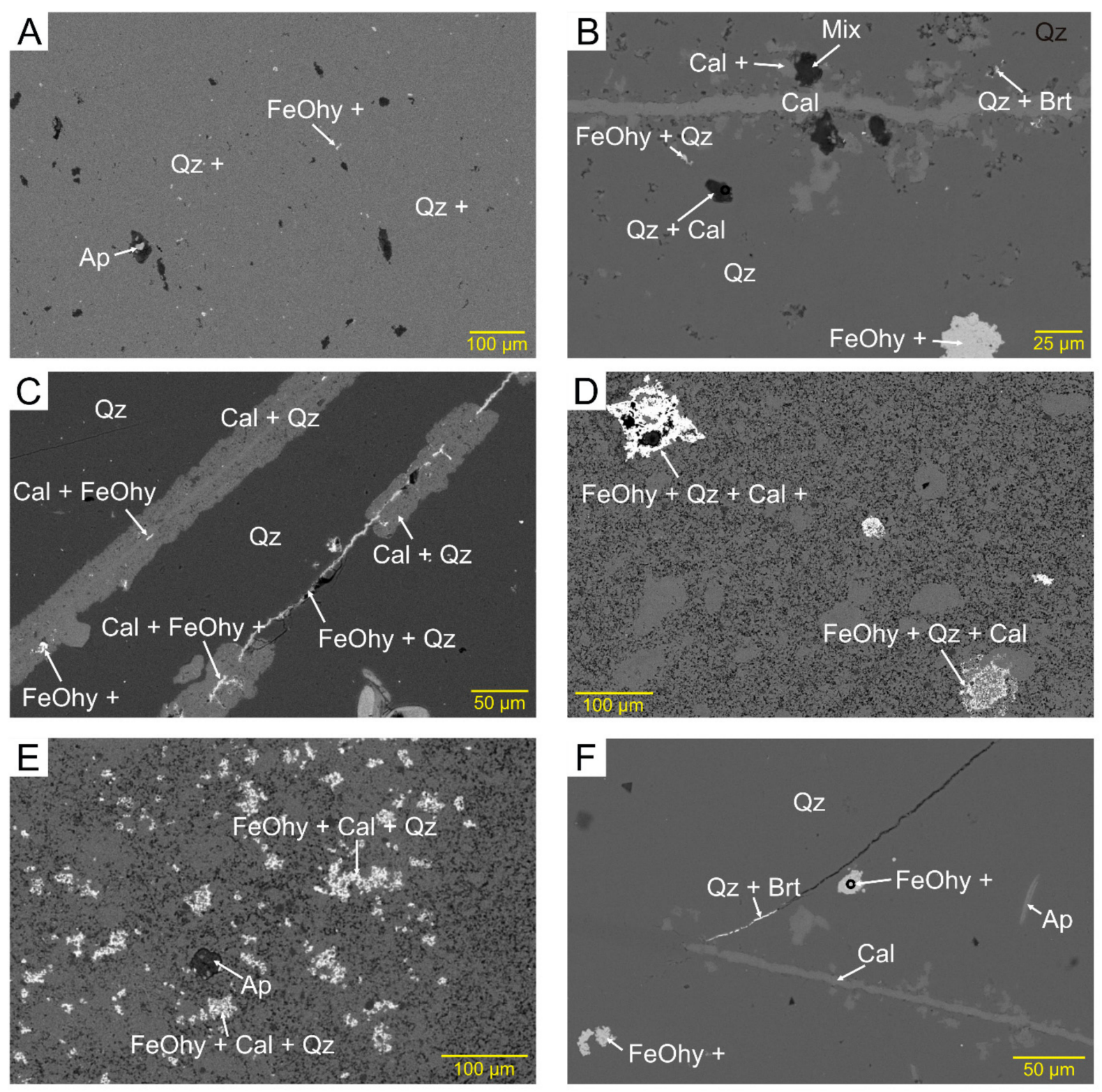

Figure 7. Backscattered electron images showing veinlets and distribution of FeOhy: (A,B) FeOhy and apatite fill pores (ARK2, AX1C); (C) calcite veins cut by hairline FeOhy veinlets (SK5); (D) scheme 5; (E) mixed zone of chert and calcite with microcrystalline aggregates of FeOhy (SK5); (F) calcite veinlet, barite partly filling hairline fracture, FeOhy aggregates in pores (AX1C).

\subsubsection{Iron Oxides and Hydroxides}

All studied samples, from both Araxos and Kastos, contain a mineral or minerals identified chemically only as Fe oxide-hydroxide (FeOhy). Measured totals of the chemical analyses for this mineral (analyses with only $\mathrm{FeO}$ and $<10 \% \mathrm{SiO}_{2}$ and $<5 \% \mathrm{CaO}$ from the 
host rock) are low and this suggests a missing component (probably $\mathrm{H}_{2} \mathrm{O}$ ). In analyses recalculated to $100 \%$, FeO content averages $90 \%$ (s.d. = 3) for sample $\mathrm{AX} 1 \mathrm{~B}$ and $87 \%$ (s.d. = 3) for SK5. The conversion of all recalculated $\mathrm{FeO}$ to $\mathrm{Fe}_{2} \mathrm{O}_{3}$ gives a $\mathrm{Fe}_{2} \mathrm{O}_{3}$ range of $79-88 \%$. The simplest explanation for these data is that there was probably originally magnetite, now partly altered to goethite.
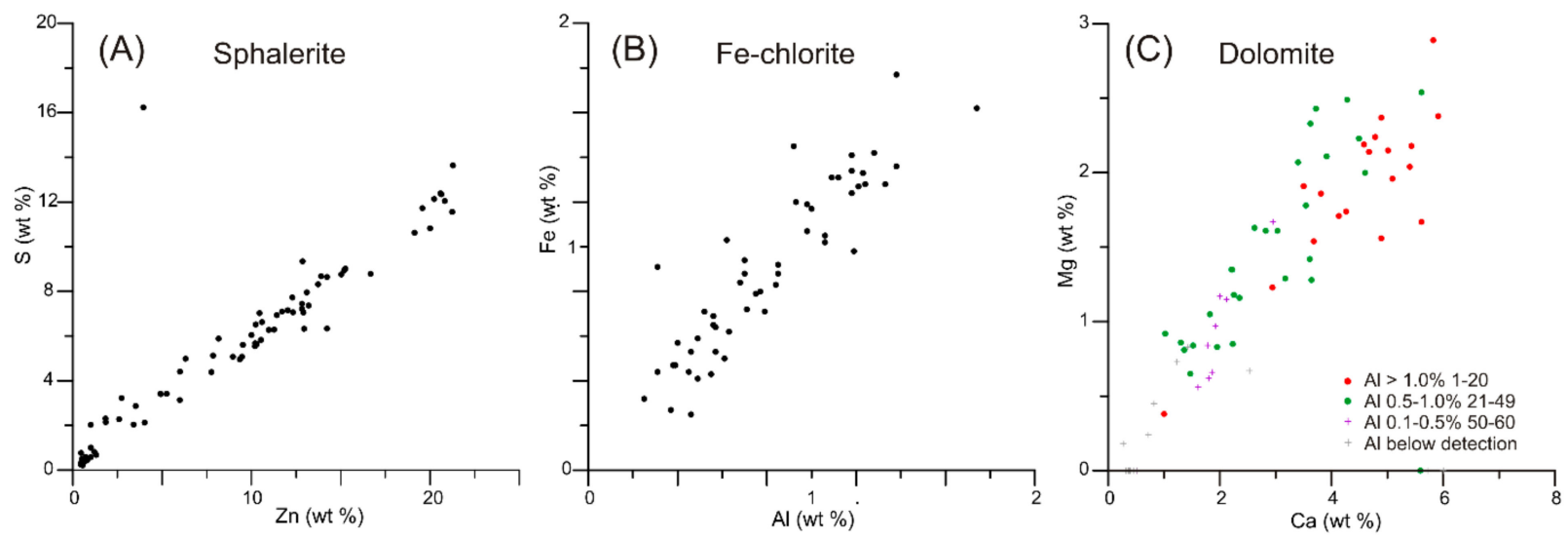

Figure 8. Plots of elements characteristic of the minerals: (A) sphalerite (S-Zn); (B) Fe-chlorite (Al-Fe); (C) dolomite (Ca-Mg). Data in Appendix A10. The concentrations of the elements in each pair decrease as the dilution by quartz and/or calcite increases, while the positive correlation of the elements in each pair remains.

In the studied samples from Araxos, FeOhy mineral grains occupy micropores of various sizes (e.g., Figure 5B,C). None have been seen in veinlets accompanying sphalerite and/or calcite. Rather, the calcite veinlets appear to cut and thus postdate FeOhy (Figure $4 \mathrm{C}, \mathrm{D}$ ). The FeOhy grains are more common in the quartz zones, although they are also present in the mixed zones. Some FeOhy grains occur in clusters (e.g., Figure 4C,D).

In the two samples from Kastos, FeOhy grains are common to very common. In sample SK5, some FeOhy fills micropores and some forms porous clusters joined by hairline veinlets within a calcite patch (Figure 4F). FeOhy also forms hairline veinlets within the calcite veins, thus postdating the vein calcite (e.g., Figure 7C). Finally, FeOhy may occur as intergrown clusters and patches (Figure 7D,E).

Many FeOhy analyses from Araxos contain detectable amounts of $\mathrm{Cu}$, and less commonly, Ni and Zn (Table 1). Cu is present in $38 \%$ of all analyses of FeOhy with a mean abundance of $1.29 \mathrm{wt} \% \mathrm{CuO}$. None of the three metals correlates with other minor components such as $\mathrm{Al}$ or $\mathrm{Ca}$, suggesting that they are associated with FeOhy. In contrast, $\mathrm{Cu}$ was detected in only two analyses of FeOhy from Kastos, and no Ni or Zn was encountered.

Table 1. Abundance of $\mathrm{Ni}, \mathrm{Cu}$, and $\mathrm{Zn}$ in Fe oxide-hydroxide analyses.

\begin{tabular}{|c|c|c|c|c|c|c|}
\hline & \multicolumn{3}{|c|}{ Araxos $n=109$} & \multicolumn{3}{|c|}{ Kastos $n=40$} \\
\hline & $\mathrm{NiO}$ & $\mathrm{CuO}$ & $\mathrm{ZnO}$ & $\mathrm{NiO}$ & $\mathrm{CuO}$ & $\mathrm{ZnO}$ \\
\hline$\%$ of analyses with values $>0$ & 14 & 38 & 5 & 0 & 5 & 0 \\
\hline Mean of analysis values that are $>0(w t \%)$ & 0.84 & 1.29 & 0.99 & 0 & 3.75 & 0 \\
\hline $\begin{array}{r}\text { All FeOhy analyses with }<2 \% \mathrm{Al}_{2} \mathrm{O}_{3} \text { and }<3 \\
\text { Wt } \% \text { corrected for dilution by } \mathrm{SiO}_{2}\end{array}$ & $\mathrm{CaO}$ & & & & & \\
\hline
\end{tabular}

\subsubsection{Pyrite}

Pyrite is identified in only two samples: it is common in AX3 and rare in AX2, both from Araxos. In both samples, most pyrite fills micropores (Figure 4E). An aggregate of pyrite crystals cuts a hairline fracture, which, in turn, is cut by a fracture partly filled with calcite (Figure 4E). However, in another analysis site in the same sample (Figure 5F), pyrite occurs as bright specks in both the quartz zone and the calcite vein. These observations 
suggest that pyrite is probably synchronous with the calcite veins or is younger. Several pyrite analyses in both samples contain Ni up to $2.7 \%$ and/or Co up to $4.1 \%$. In Kastos, only one pyrite grain filling a micropore has been found in sample SK5, without detectable $\mathrm{Ni}$ or Co.

\subsubsection{Apatite}

The abundance and mode of occurrence of sedimentary apatite (francolite) are quite variable. It is common in sample AX3 from Araxos and in sample SK5 from Kastos but much less common in all other studied samples. It occurs in very variable forms. Some apatite is clearly of original biogenic origin, in occasional shells or fragments of shells (Figure 9A,B) and as small peloids (Figure 9C). Other apatite grains appear to completely or partly fill voids in the chert (Figure 9D,E) or rarely form irregular veinlets, probably along quartz crystallite boundaries. Some apatite resembles needles or spicules. Some of these might be biogenic, whereas others may be straight examples of veinlets. In addition to these clear modes of occurrence, in almost every sample there are scattered micron-sized specks with bright backscatter and elevated amounts of $\mathrm{P}_{2} \mathrm{O}_{5}$, with the rest of the $10 \mathrm{~m}$ analysed spot being mostly $\mathrm{SiO}_{2}$.
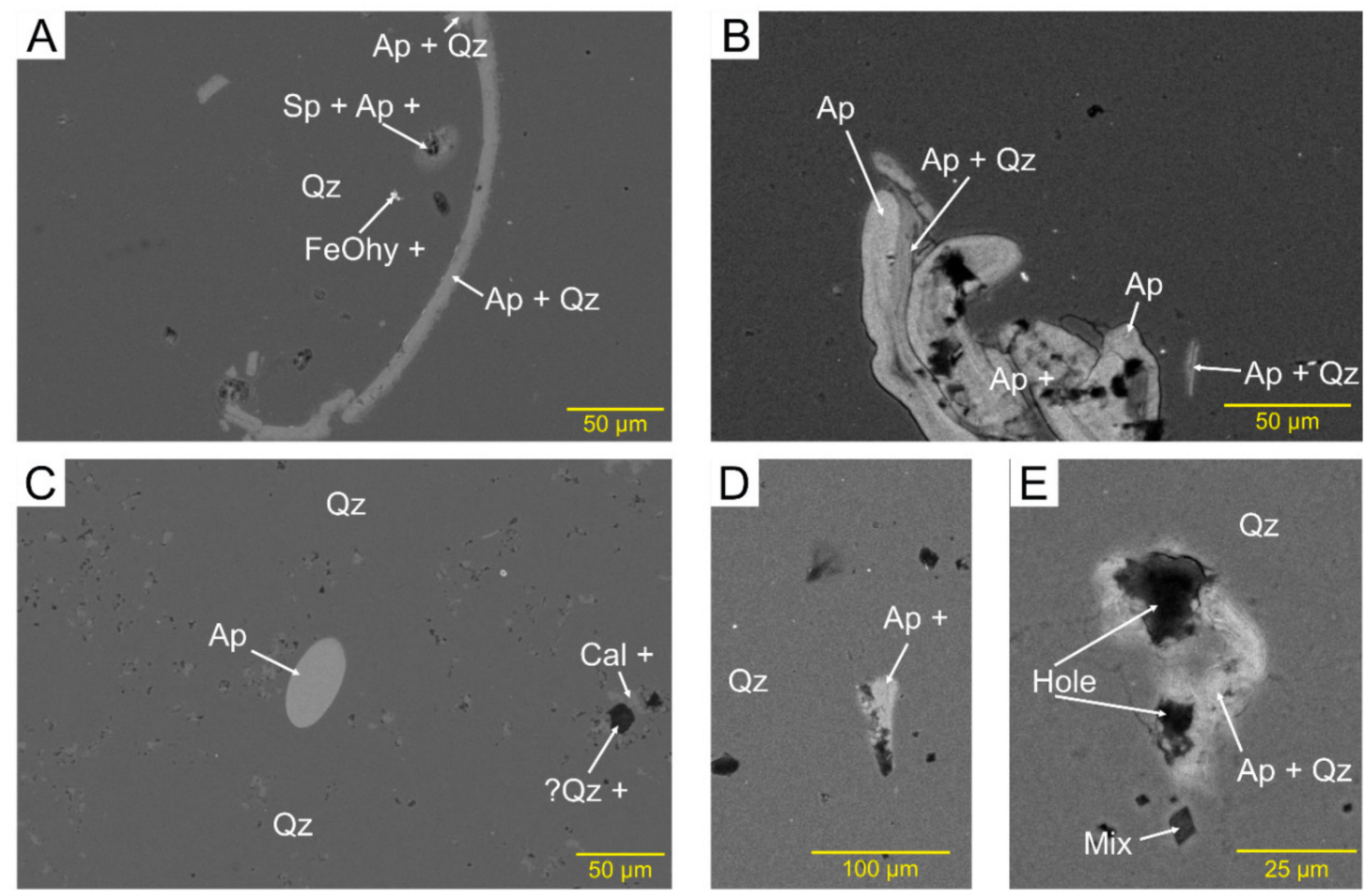

Figure 9. Backscattered electron images showing modes of occurrence of apatite: (A) shell fragment of apatite (AX1B); (B) shell fragments, either originally or replaced by apatite (SK5); (C) peloid of apatite (AX1C); (D,E) two micropores filled with apatite (note different magnifications) (AX3).

Apatite grains consist principally of $\mathrm{Ca}_{5}\left(\mathrm{PO}_{4}\right)_{3}$ but have distinctive minor element chemistry with most grains including $\sim 1 \% \mathrm{Na}_{2} \mathrm{O}, \sim 2 \% \mathrm{SO}_{3}{ }^{+}$, and mostly $5-7 \% \mathrm{~F}$ (Figure 10). A few analyses with $<38 \% \mathrm{P}_{2} \mathrm{O}_{5}$ are interpreted as including some calcite and are excluded from further consideration. Clearly, biogenic shells and peloids tend to have a little less $\mathrm{Na}_{2} \mathrm{O}$ and $\mathrm{SO}_{3}$ than clearly later apatite that rims voids or in veinlets (Figure $10 \mathrm{~b}, \mathrm{c}$ ). The variation of $\mathrm{F}$ with a mode of occurrence appears random and has not been illustrated. Some specks and spicules/veinlets have $\mathrm{SO}_{3}$ characteristic of biogenic material, but the majority show elevated $\mathrm{SO}_{3}$ suggesting a later diagenetic origin. 

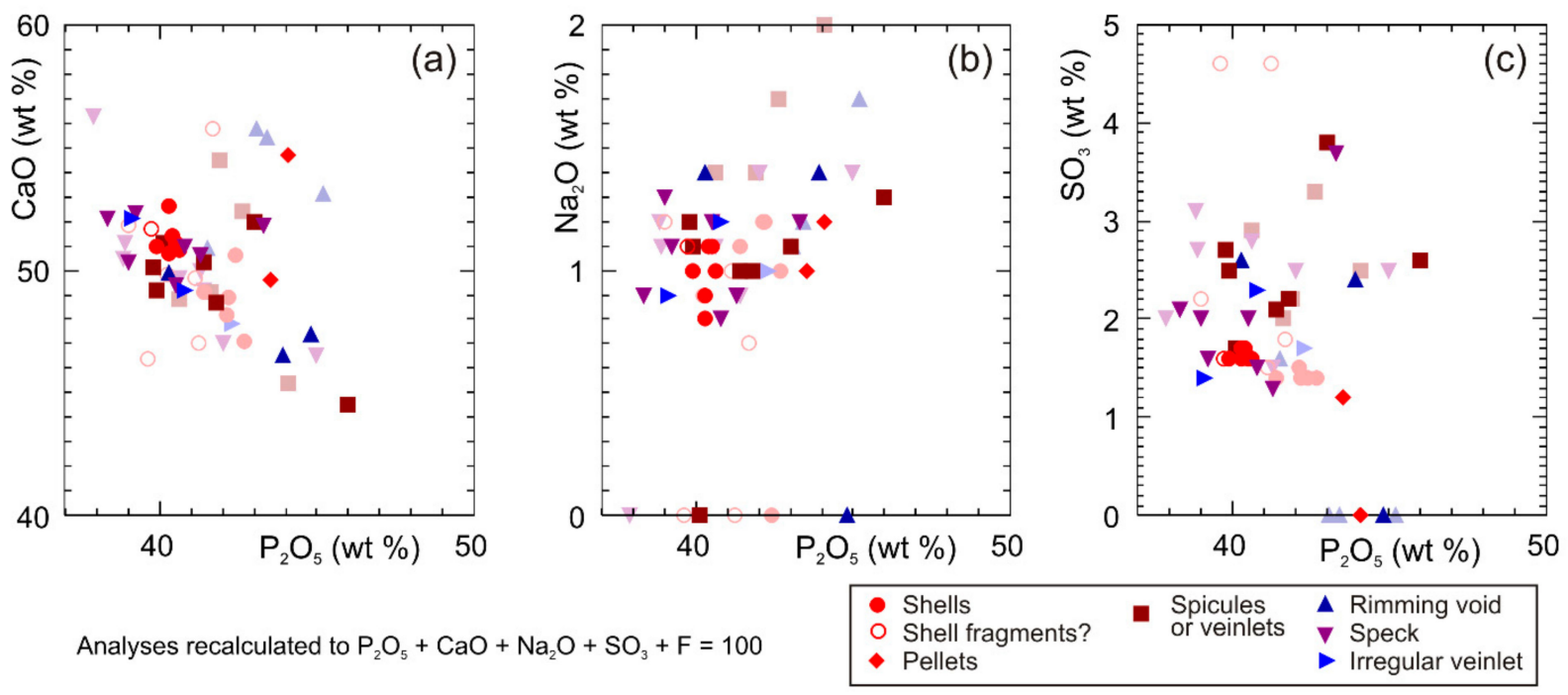

Figure 10. Plots of elements as oxides vs. $\mathrm{P}_{2} \mathrm{O}_{5}$ in apatite showing different morphological types: (a) $\mathrm{CaO} ;(\mathbf{b}) \mathrm{Na}_{2} \mathrm{O}$; (c) $\mathrm{SO}_{3}$. Analyses have been recalculated to $\mathrm{P}_{2} \mathrm{O}_{5}+\mathrm{CaO}+\mathrm{Na}_{2} \mathrm{O}+\mathrm{SO}_{3}+\mathrm{F}=100$, to remove the effects of the host silica on analyses of small apatite grains. Morphological types are presented in more detail in the text.

\subsubsection{Other Minor Minerals}

Two other minor minerals are identified in sample AX1 from Araxos, based on their chemical composition: chlorite and dolomite. The presence of chlorite is suggested by the coexistence of $\mathrm{Si}, \mathrm{Al}, \mathrm{Fe}$, and $\mathrm{Mg}$ in analyses of some aggregates. Systematic covariation of $\mathrm{Fe}$ and $\mathrm{Al}$ (Figure $8 \mathrm{~B}$ ) is interpreted as representing chlorite. The presence of dolomite is suspected from the presence of $\mathrm{Mg}$ when $\mathrm{Ca}$ is high, and there is no significant $\mathrm{Al}$ in the analysis. Dolomite is confirmed by the covariation of $\mathrm{Ca}$ and $\mathrm{Mg}$ (Figure 8C), and a lack of correlation between $\mathrm{Mg}$ and $\mathrm{Fe}$ that would indicate significant $\mathrm{Mg}$ in chlorite.

\section{Discussion}

\subsection{General Timing of Diagenetic Stages and Contrasts between Araxos and Kastos}

The observed microporosity appears to predate the fracturing of the rock, and it is probably due to volume reduction that took place during the recrystallisation of amorphous silica to microcrystalline quartz [6]. Microporosity is cut by veinlets $10-30 \mu \mathrm{m}$ wide that tend to be perpendicular to bedding (Figure 3C,D) and, in many cases, are filled with calcite (Figure 4). Barite, sphalerite, and FeOhy veins all appear later than most calcite veins.

Araxos and Kastos differ in the degree of structural deformation and distance from active salt tectonics systems. The Araxos samples, compared to the Kastos samples, look more deformed and with much higher microporosity, although this may result from more residual calcite in the Kastos samples. Sphalerite has only been found in the Araxos concretions and barite is by far more common in the Araxos concretions. The FeOhy analyses from the Araxos samples (Table 1) contain much more $\mathrm{Cu}, \mathrm{Ni}$, and $\mathrm{Zn}$ as minor components, compared to Kastos samples.

\subsection{The Origin of Sedimentary Apatite}

Much of the sedimentary apatite formed under seafloor conditions. Phosphate authigenesis is described as common in the Coniacian (-Santonian) (i.e., lower Senonian Limestones) of the northeastern part of the deep-water central Ionian zone, associated with low oxygenation of seawater $[17,18]$. In the Kastos and Araxos sections, there is no evidence for widespread phosphatisation. Most fossil fragments in the studied samples consist of calcium carbonate, and a few shell fragments are phosphatic, likely from brachiopods. Some phosphatic spicules with lower $\mathrm{Na}_{2} \mathrm{O}$ and $\mathrm{SO}_{3}$ may also be biogenic, possibly derived 
from siphonophores [23]. Apatite peloids are rare and thus likely indicative of only local seafloor phosphatic authigenesis.

Apatite in specks in pores and in veinlets, together with some spicules, tends to have higher $\mathrm{SO}_{3}$. Texturally, it appears to be late diagenetic and the elevated $\mathrm{SO}_{3}$ suggests basinal fluids related to the dissolution of anhydrite.

\subsection{The Sphalerite-Barite Mineral Association}

Barite and sphalerite both fill microporosity at Araxos and appear related. Barium in diagenetic systems is generally considered to be derived from the breakdown, albitisation or dissolution, of detrital K-feldspar, from clastic source rocks. The most likely such source in the Ionian zone is from Permian-Triassic terrestrial clastic rocks overlying the Hercynian basement and underlying Triassic evaporites. Many of these rocks immediately east of the Ionian zone are dominantly quartzitic (the Phyllite-Quartzite series: [12]). However, the underlying Hercynian basement includes granitic gneiss in Kythira [24] and Triassic granitic lithic clasts were supplied to Pliocene sediments near Patras [25], suggesting the potential for local deposition of arkose. Crystallisation temperatures for hydrothermal barite range from 70 to $250{ }^{\circ} \mathrm{C}$ [26], and barite associated with sphalerite, galena, or other sulphides probably has higher temperatures of formation [27].

The zinc in diagenetic systems is generally considered to be derived from biogenic $\mathrm{Zn}$ substituted in aragonite and calcite [28], and its abundance in the carbonate rocks ranges from 0 to $50 \mathrm{ppm}$ [29]. The crystallisation of sphalerite generally takes place at $140-200{ }^{\circ} \mathrm{C}$ [26]. Pyrite is common in the samples from Araxos, and this suggests reducing conditions during the diagenesis of these samples. Under such conditions, the transport of the $\mathrm{Zn}$ cations is favoured by chloride complexes in basinal brines [30]. Transport of $\mathrm{Zn}$ in the form of chloride complexes in quantities enough to form sphalerite requires salinity of $\sim 17 \% \mathrm{NaCl}$ equivalent [31]. The presence of sphalerite thus suggests basinal fluids derived from the dissolution of halite.

Alternatively, the source of both $\mathrm{Ba}$ and $\mathrm{Zn}$, together with elevated $\mathrm{S}$ and $\mathrm{P}$, may be from the black shale horizons of the Ionian zone. Although there are no reported inorganic chemical analyses from the several non-phosphatic Mesozoic black shale horizons in the Ionian zone (e.g., [32,33]), such shales elsewhere are commonly enriched in $\mathrm{Ba}$, redoxsensitive (U, Mo, Re, V, Cr), and sulphide-forming metals ( $\mathrm{Cu}, \mathrm{Ni}, \mathrm{Cd}, \mathrm{Zn})$ [34]. Bulk limestones from the Ionian zone are enriched in $\mathrm{Ba}, \mathrm{Bi}, \mathrm{Co}$, and $\mathrm{Cu}$ compared to the global average limestone [35]. Ni, $\mathrm{Cu}$, and $\mathrm{Zn}$ are associated with FeOhy minerals filling microporosity and veinlets, particularly at Araxos.

\subsection{Tectonic Control at Araxos and Kastos}

Paleogene fold and thrust deformation of the Ionian zone resulted in decollement along evaporite horizons and supracrustal shortening potentially producing overpressure. Salt-cored anticlines locally evolved into salt diapirs and salt walls $[16,36]$ and the local elevation of Cretaceous strata at Araxos is related to such diapirism. The relief at Kastos Island is a continuation of that along strike to the north and does not show evidence for diapirism. We, therefore, conclude that the distribution pattern for sphalerite and barite between Araxos and Kastos reflects the availability of basinal fluids with the high salinity in the diagenetic system that has affected the Araxos Cretaceous rocks. Similar barite-sphalerite mineralisation is known from other petroleum basins with strong salt tectonics [37].

Basinal fluids with the right chemical species, in this case, $\mathrm{Zn}, \mathrm{Ba}, \mathrm{Fe}$, and $\mathrm{S}$, under reducing conditions and high salinity, require pathways for effective circulation and precipitation of the late diagenetic/hydrothermal minerals. At a macro scale, the widespread Paleogene thrust faults and Neogene normal faults provide potential pathways. On a local scale, bedding parallel joints in limestone may be important pathways (Figure 3A,B). Joints are abundant within chert concretions, principally orthogonal to bedding, and propagate only a short distance into host limestone [9]. In the studied concretions, the sites of deposi- 
tion of such minerals include voids due to microporosity, bedding planes, and a variety of microfractures with different morphology and orientation. These are exactly the sites where all the late minerals, diagenetic or hydrothermal, described from the studied concretions, have been seen (Figures 3-5). These figures show the pathways that the basinal fluid followed, as well as the more intensive fracturing of the Araxos samples relative to that of Kastos (e.g., Figure 3). The micropores, and particularly the microfractures, are further filled with a few other minerals that include apatite, chlorite, and rare titania minerals (e.g., sample AX3). We cannot distinguish between (1) a possible deep-seated source of metals, in which $\mathrm{Ba}$ is derived from late Paleozoic arkosic sandstone, Fe from Mesozoic and late Paleozoic shales, and $\mathrm{Zn}$ and P from the Mesozoic carbonates, and (2) remobilisation of metals enriched in Mesozoic black shale horizons.

\subsection{Silica Concretions as Recorders of Basinal Fluids}

The preservation of microporosity in chert concretions with microcrystalline quartz and the formation of joints that die out in the host limestone make chert horizons particularly permeable. In thick limestone-shale successions, such as in the Ionian zone, cherts partly fulfil a role played by sandstones in more clastic basins. Together with faults and some bedding planes in limestones, they can act as fairways for fluid migration, including hydrocarbons. Submillimetre size diagenetic minerals that precipitate in pores and joints provide a record of that fluid flow. The transport of sphalerite at Araxos requires hot saline fluids derived from Triassic halite, whereas the mineral assemblage at Kastos with some barite could have formed at lower, less saline conditions. Late diagenetic francolite has higher $\mathrm{SO}_{3}$ content than seafloor shells and peloids, suggesting the involvement of sulphate-rich waters from Triassic anhydrite.

\section{Conclusions}

Nodular chert in limestone successions provides a particularly good record of late diagenetic fluid movement in two types of sites: microporosity produced by recrystallisation of opal to quartz and fractures produced in the brittle chert during basin inversion.

Diagenetic minerals in pores and veins include sedimentary apatite (francolite), dolomite, Fe-chlorite, Fe oxide-hydroxide mixtures (FeOhy), sphalerite, barite, and calcite. Minor minerals include zincite, pyrite, pyrrhotite. monazite, zircon, ilmenite, and a titania mineral.

The rocks at Araxos are highly faulted and are likely related to a salt diaper. The rocks at Kastos are exposed on the flank of a regional anticline. Sphalerite is restricted to Araxos, where FeOhy includes minor amounts of $\mathrm{Cu}, \mathrm{Zn}$, and Ni. This suggests that basinal fluids were hotter and more saline than at Kastos. Whether the transported metals were derived from sub-salt clastic rocks and basement or from enriched Mesozoic black shales is unknown.

Supplementary Materials: The following are available online at https:/ / www.mdpi.com/article/10 $.3390 / \min 11070763 / \mathrm{s} 1$, Supplementary Material S1-S13, SEM and EDS data in pdf format.

Author Contributions: Conceptualisation, G.P.-P., D.J.W.P., N.B. and A.Z.; methodology, G.P.-P.; field studies N.B. and A.Z.; data curation, G.P.-P. and N.B.; data interpretation, G.P.-P. and D.J.W.P.; writing-original draft preparation, G.P.-P. and D.J.W.P.; writing—review and editing, N.B. and A.Z.; funding acquisition, G.P.-P. and A.Z. All authors have read and agreed to the published version of the manuscript.

Funding: Laboratory work was supported by a Natural Sciences and Engineering Council of Canada Discovery Grant to GPP (2016-04310).

Data Availability Statement: Data are available in Supplementary Materials (see above).

Acknowledgments: We thank Gabriel Garcia Gomez and Justin Nagle, for their assistance with the SEM work, and three anonymous reviewers for constructive advice. 
Conflicts of Interest: The authors declare no conflict of interest. The funders had no role in the design of the study; in the collection, analyses, or interpretation of data; in the writing of the manuscript, or in the decision to publish the results.

\section{References}

1. Zijlstra, H.J. Early diagenetic silica precipitation, in relation to redox boundaries and bacterial metabolism, in Late Cretaceous chalk of the Maastrichtian type locality. Geol. Mijnb. 1987, 66, 343-355.

2. Bohrmann, G.; Abelmann, A.; Gersonde, R.; Hubberten, H.; Kuhn, G. Pure siliceous ooze, a diagenetic environment for early chert formation. Geology 1994, 22, 207-210. [CrossRef]

3. Madsen, H.B.; Stemmerik, L. Diagenesis of flint and porcellanite in the Maastrichtian chalk at Stevns Klint, Denmark. J. Sediment. Res. 2010, 80, 578-588. [CrossRef]

4. Sears, S.O. Porcelaneous cement and microporosity in California Miocene turbidites; origin and effect on reservoir properties. J. Sediment. Res. 1984, 54, 159-169.

5. Watney, W.L.; Guy, W.J.; Byrnes, A.P. Characterization of the Mississippian chat in south-central Kansas. AAPG Bull. 2001, 85, 85-113.

6. Hussein, A.W.; Abd El-Rahman, Y.M. Origin of chert within the Turonian carbonates of Abu Roash Formation, Abu Roash area, Egypt: Field, petrographic, and geochemical perspectives. Geol. J. 2020, 55, 2805-2833. [CrossRef]

7. He, J.; Ding, W.; Huang, W.; Cao, Z.; Chen, E.; Dai, P.; Zhang, Y. Petrological, geochemical, and hydrothermal characteristics of Ordovician cherts in the southeastern Tarim Basin, NW China, and constraints on the origin of cherts and Permian tectonic evolution. J. Asian Earth Sci. 2019, 170, 294-315. [CrossRef]

8. Kochman, A.; Kozłowski, A.; Matyszkiewicz, J. Epigenetic siliceous rocks from the southern part of the Kraków-Częstochowa Upland (Southern Poland) and their relation to Upper Jurassic early diagenetic chert concretions. Sediment. Geol. 2020, 401, 105-636. [CrossRef]

9. Antonellini, M.; Del Sole, L.; Mollema, P.N. Chert nodules in pelagic limestones as paleo-stress indicators: A 3D geomechanical analysis. J. Struct. Geol. 2020, 132, 103-979. [CrossRef]

10. Mattavelli, L.; Pieri, M.; Groppi, G. Petroleum exploration in Italy: A review. Mar. Pet. Geol. 1993, 10, 410-425. [CrossRef]

11. Cassinis, G.; Perotti, C.; Santi, G. Post-Variscan Verrucano-like deposits in Italy, and the onset of the alpine tectono-sedimentary cycle. Earth Sci. Rev. 2018, 185, 476-497. [CrossRef]

12. Robertson, A.H. Sedimentary evidence from the south Mediterranean region (Sicily, Crete, Peloponnese, Evia) used to test alternative models for the regional tectonic setting of Tethys during Late Palaeozoic-Early Mesozoic time. Geol. Soc. Lond. Spec. Publ. 2006, 260, 91-154. [CrossRef]

13. Pomoni-Papaioannou, F.; Karakitsios, V.; Kamberis, E.; Marnelis, F. Chevron-type halite and nodular anhydrite in the Triassic subsurface evaporites of the Ionian zone (western Greece). Bull. Geol. Soc. Greece 2004, 36, 578-586. [CrossRef]

14. Lugli, S. Timing of post-depositional events in the Burano Formation of the Secchia valley (Upper Triassic, Northern Apennines), clues from gypsum-anhydrite transitions and carbonate metasomatism. Sediment. Geol. 2001, 140, 107-122. [CrossRef]

15. Karakitsios, V. Western Greece and Ionian Sea petroleum systems. AAPG Bull. 2013, 97, 1567-1595. [CrossRef]

16. Zelilidis, A.; Maravelis, A.G.; Tserolas, P.; Konstantopoulos, P.A. An overview of the petroleum systems in the Ionian Zone, onshore NW Greece and Albania. J. Pet. Geol. 2015, 38, 331-348. [CrossRef]

17. Serjani, A. On the extension and lithological-facial composition of the Upper Cretaceous phosphatic horizon in the Ionian Zone. Geol Balk. 1991, 21, 59-68.

18. Skourtsis-Coroneou, V.; Solakius, N.; Constantinidis, I. Cretaceous stratigraphy of the Ionian Zone, Hellenides, western Greece. Cretac. Res. 1995, 16, 539-558. [CrossRef]

19. Velaj, T.; Davison, I.; Serjani, A.; Alsop, I. Thrust tectonics and the role of evaporites in the Ionian Zone of the Albanides. AAPG Bull. 1999, 83, 1408-1425.

20. Bourli, N.; Kokkaliari, M.; Iliopoulos, I.; Pe-Piper, G.; Piper, D.J.W.; Maravelis, A.G.; Zelilidis, A. Mineralogy of siliceous concretions, cretaceous of ionian zone, western Greece: Implication for diagenesis and porosity. Mar. Pet. Geol. 2019, 105, 45-63. [CrossRef]

21. Pe-Piper, G.; Piper, D.J.W.; McFarlane, C.R.; Sangster, C.; Zhang, Y.; Boucher, B. Petrology, chronology and sequence of vein systems: Systematic magmatic and hydrothermal history of a major intracontinental shear zone, Canadian Appalachians. Lithos 2018, 304, 298-310. [CrossRef]

22. Whitney, D.L.; Evans, B.W. Abbreviations for names of rock-forming minerals. Am. Mineral. 2010, 95, 185-187. [CrossRef]

23. Mackie, G.O.; Marx, R.M. Phosphatic spicules in the nematocyst batteries of Nanomia cara (Hydrozoa, Siphonophora). Zoomorphology 1988, 108, 85-91. [CrossRef]

24. Xypolias, P.; Dürr, W.; Zulauf, G. Late Carboniferous plutonism within the pre-Alpine basement of the External Hellenides (Kithira, Greece): Evidence from U-Pb zircon dating. J. Geol. Soc. Lond. 2006, 163, 539-547. [CrossRef]

25. Pe-Piper, G.; Koukouvelas, I. Petrology and geochemistry of granitic pebbes in the Pliocene fluvial deposits of the northwest Peloponnese (Greece) and their regional significance. Neues Jahrb. Für Mineral. Abh. 1990, 161, 327-343.

26. Samson, I.M.; Russell, M.J. Genesis of the Silvermines zinc-lead-barite deposit, Ireland; fluid inclusion and stable isotope evidence. Econ. Geol. 1987, 82, 371-394. [CrossRef] 
27. Davis, A.S.; Clague, D.A.; Zierenberg, R.A.; Wheat, C.G.; Cousens, B.L. Sulfide formation related to changes in the hydrothermal system on Loihi Seamount, Hawai'i, following the seismic event in 1996. Can. Mineral. 2003, 41, 457-472. [CrossRef]

28. Pingitore, N.E. The behavior of $\mathrm{Zn} 2+$ and $\mathrm{Mn} 2+$ during carbonate diagenesis; theory and applications. J. Sediment. Res. 1978, 48, 799-814.

29. Heinrichs, H.; Schulz-Dobrick, B.; Wedepohl, K.H. Terrestrial geochemistry of Cd, Bi, Tl, Pb, Zn and Rb. Geochim. Et Cosmochim. Acta 1980, 44, 1519-1533. [CrossRef]

30. Giordano, T.H. Transport of $\mathrm{Pb}$ and $\mathrm{Zn}$ by carboxylate complexes in basinal ore fluids and related petroleum-field brines at 100 ${ }^{\circ} \mathrm{C}$ : The influence of $\mathrm{pH}$ and oxygen fugacity. Geochem. Trans. 2002, 3, 56-72. [CrossRef]

31. Hanor, J.S. Variations in chloride as a driving force in siliciclastic diagenesis. In Siliciclastic Diagenesis and Fluid Flow: Concepts and Applications; Crossey, L.J., Loucks, R., Totten, M.W., Scholle, P.A., Eds.; SEPM Special Publication: Broken Arrow, OK, USA, 1996; Volume 55, pp. 4-12.

32. Tsikos, H.; Karakitsios, V.; van Breugel, Y.; Walsworth-Bell, B.E.; Bombardiere, L.; Petrizzo, M.R.; Damsté, J.S.; Schouten, S.; Erba, E.; Silva, I.P.; et al. Organic-carbon deposition in the Cretaceous of the Ionian Basin, NW Greece: The Paquier Event (OAE 1b) revisited. Geol. Mag. 2004, 141, 401-416. [CrossRef]

33. Danelian, T.; Baudin, F.; Gardin, S.; Masure, E.; Ricordel, C.; Fili, I.; Meçaj, T.; Muska, K. The record of mid Cretaceous oceanic anoxic events from the Ionian zone of southern Albania. Rev. Micropaléontologie 2007, 50, 225-237. [CrossRef]

34. Meyers, P.A.; Bernasconi, S.M.; Forster, A. Origins and accumulation of organic matter in expanded Albian to Santonian black shale sequences on the Demerara Rise, South American margin. Org. Geochem. 2006, 37, 1816-1830. [CrossRef]

35. Bourouni, P.; Tsikouras, B.; Hatzipanagiotou, K. Petrological investigation of carbonate rocks from the Ionian zone (Etoloakarnania, western Greece). Bull. Geol. Soc. Greece 2010, 43, 2540-2552. [CrossRef]

36. Monopolis, D.; Bruneton, A. Ionian Sea (Western Greece): Its structural outline deduced from drilling and geophysical data. Tectonophysics 1982, 83, 227-242. [CrossRef]

37. Pe-Piper, G.; Piper, D.J.W.; Zhang, Y.; Chavez, I. Diagenetic barite and sphalerite in middle Mesozoic sandstones, Scotian Basin, as tracers for basin hydrology. AAPG Bull. 2015, 99, 1281-1313. [CrossRef] 